\title{
From genitive suffix to linking element
}

A corpus study on the genesis and productivity of a new compounding pattern in (Early) New High German*

\author{
Kristin Kopf \\ University of Münster
}

\begin{abstract}
Present-day German uses two formally different patterns of compounding in $\mathrm{N}+\mathrm{N}$ compounds. The first combines bare stems (e.g. Tisch+decke 'tablecloth') while the second contains an intervening linking element (LE) as in Geburt-s-ort 'birth-LE-place'. The linked compounding type developed in Early New High German (1350-1650) from phrasal constructions by reanalyzing genitive attributes as first constituents of compounds. The present paper uses corpus data to explore three key stages in this development: In the initial stage, it shows how prenominal non-specific genitive constructions lent themselves to reanalysis due to their functional overlap and formal similarity. Additionally, compounds seem to have replaced not only prenominal genitives, but also structurally different postnominal genitives. In the second stage, the new compounding pattern increases in productivity between 1500 and 1710 , especially compared to the older pattern without linking elements. The last stage pertains to changes in spelling practice. It shows that linked compounds were written
\end{abstract}

* I thank the editors, two anonymous reviewers, Damaris Nübling, Susanne Flach and Ulrike Schneider for their helpful comments.

The data and analysis offered here have since been expanded on and superceded by Kopf (2016), which defines compounds in a different way. However, as this paper takes a more traditional approach, its data is better suited for comparison with earlier studies. 
separately in the beginning. Their gradual graphematic integration into directly connected words was reversed by a century of hyphenation (1650-1750). This is strikingly different from present-day spelling practice and shows that the linked pattern was still perceived as marked.

\section{Introduction}

Nominal compounds in German come in one of two forms: In the first one, similar to English, the two nouns are simply combined (Tisch+decke 'tablecloth'). The second makes use of intervening linking elements (LE) (Geburt-s-ort 'birth-LE-place', Akte-n-ordner 'file-LE-folder'), a phenomenon that can also be observed in several other Germanic languages (e.g. Dutch, Danish, Luxemburgish, c.f. Fuhrhop \& Kürschner 2015: 574-578). About $39-42 \%$ of nominal compounds in present-day German make use of linking elements (Kürschner 2003: 105; Kopf 2017), at least two of these linking elements can be traced back to genitive morphemes (cf. Pavlov 1983; Nitta 1987; Demske 2001; Nübling \& Szczepaniak 2013). Due to the frequent preposing of genitive attributes in Early New High German (1350-1650, short: ENHG), reanalysis of a genitive attribute and its head lead to a new, compound-like structure. By analogy, these former genitive suffixes spread to new formations as well as existing compounds in both of which a former inflectional origin is no longer indicated due to specific morphological or semantic properties (Infectionszeit 'infection-LE-time', bauersmann 'farmer-LE-man'). This results in a new pattern of compounding.

This process has been frequently described; however, there is still much to be learned about the constructions involved and the chronology 
of changes in syntax and morphology. Existing corpus studies are few and usually confined to smaller aspects or shorter time frames. The studies presented in this paper draw from several corpora and consider a wide range of phenomena to gain a fuller picture. They look at three stages in the development from 1500 to 1900 , going from syntax to word formation: The first study focuses on the early stages of the reanalysis process by scrutinizing suitable genitive constructions and their relation to compounds. The data suggests a process of substitution in form. The second study applies measures of morphological productivity to compounds with and without linking elements to show when we can assume a new pattern and not simply isolated cases of reanalysis. The third study uses spelling to infer the status that the new compounds hold in relation to the established pattern. This reveals large differences and an extended period of integration into word formation morphology.

\section{Phenomenon and corpora}

Whereas genitive attributes in present-day German generally follow the head noun, ${ }^{1}$ their position in ENHG was variable (Carr 1933; Ebert 1988; Demske 2001). Prenominal attributes could be reanalyzed as first constituents of compounds. While overtly marked genitives gave rise to linking elements, as in (1), reanalysis of not overtly marked genitives (i.e. feminine nouns belonging to the former $i$ - or $\bar{o}$-declension classes, as in (2a)

$1 \quad$ Personal names and personal name-like nouns (mostly kinship terms, e.g. Omas Haus 'granny's house') still form an exception (cf. Nübling, Fahlbusch \& Heuser 2012: 84-85), this applies to some other proper name classes as well. 
resulted in structures identical to those of a pre-existing compounding type which made use of bare stems, as in (2b). ${ }^{2,3,4}$

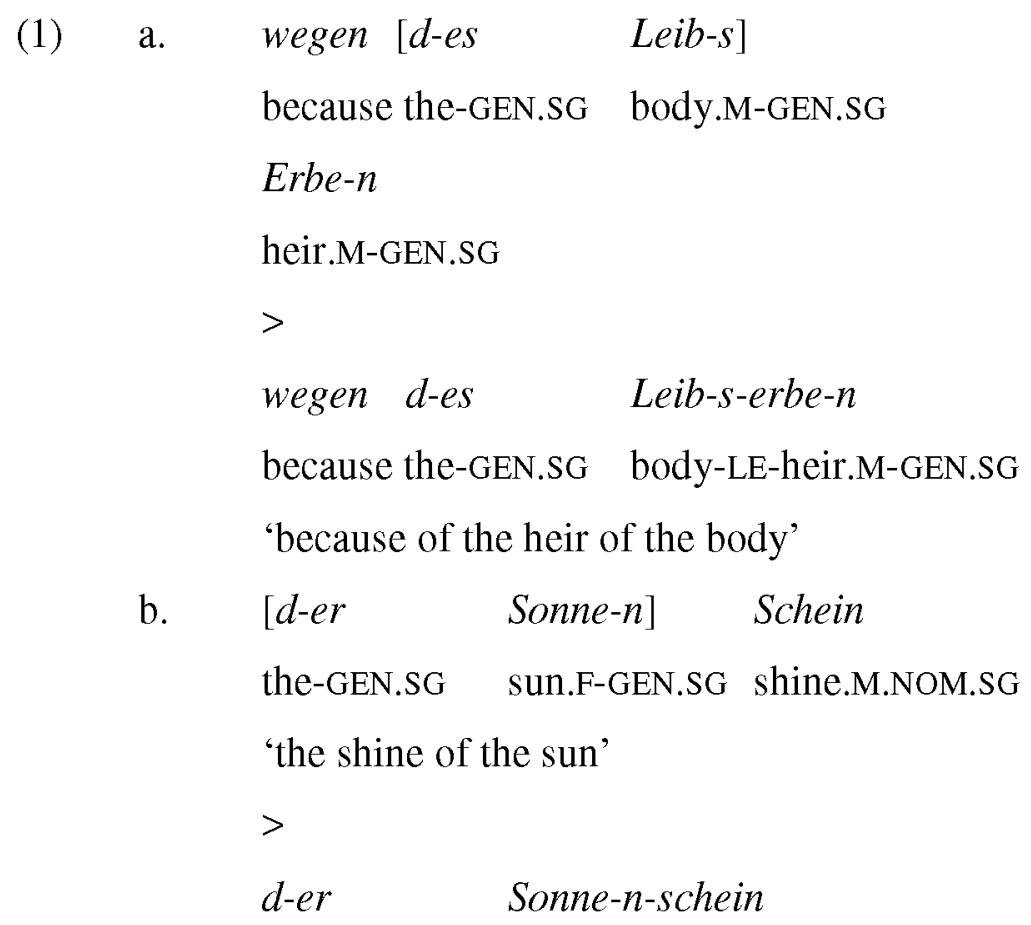

2 Older stem-forming elements also lead to linking elements in compounds, e.g. OHG tag-a-lon 'day-wage', but they play a very marginal role in today's system. (For two different views of their importance in the genesis of some linking elements, see Wegener 2008 and Nübling \& Szczepaniak 2013: 69-72.) They might, however, have helped the new linking elements along as speakers were used to the existence of additional phonological material in compounds.

3 Abbreviations used in the glosses: case: NOM - nominative, GEN genitive, DAT - dative; number: SG - singular, PL - plural; gender: F - feminine, $\mathrm{M}$ - masculine, $\mathrm{N}$ - neuter; LE - linking element. In case of syncretism, only the relevant case or number is marked. Gender is marked on the noun only, although expressed through agreement on the articles.

4 The examples used show the presumed reanalysis while maintaining the same structure. Proof for reanalysis can then be found when the compounds are used in new contexts, e.g. mit dem Leibserben 'with the heir of the body', where dem 'the.DAT.SG' can refer to Erben 'heir.DAT.SG' only. 


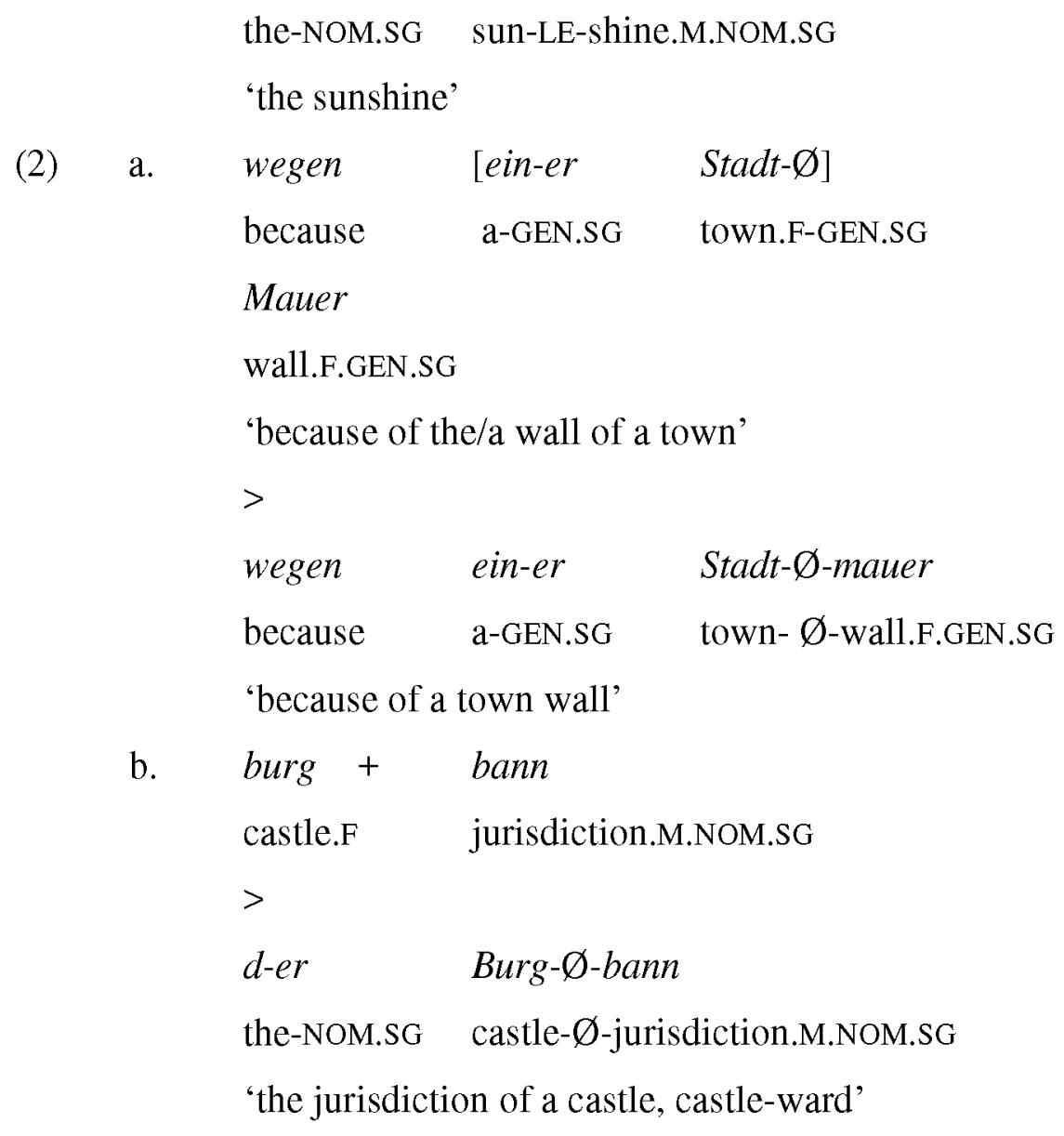

In this paper, I will call the compounds in (1) "linked compounds" and those in (2) "unlinked compounds".

All compounds analyzed here are defined by grammatical properties: A modifier or determiner clearly refers to the second nominal element but not to the first.

(3) genitive construction:
in $\quad$ ein-es
König-s]
in [a-GEN.SG
king.M-GEN.SG]
Schloss 
castle.N.NOM.SG

'in a king's castle'

(4) bridging construction:
a. in König-s
Schloss
in king.M-GEN.SG/LE castle.N.DAT.SG
'in castle of the king / in the royal castle'
b. ein-es König-s
gewahr werden
aware become
Schloss-es
a-GEN.SG king.M-GEN.SG/LE castle.N-GEN.SG
'become aware of the castle of a king / of a royal castle'

(5) compound:

\begin{tabular}{|c|c|c|}
\hline$d$-as & [König-s & Schloss $]^{5}$ \\
\hline the-NOM.SG & [king-LE & castle.N.NOM.SG] \\
\hline
\end{tabular}

In (5) the determiner das (N.NOM/ACC.SG) agrees with Schloss (N.NOM/ACC.SG) but not with Königs (M; if analyzed as case marker, $-s$ had to be GEN.SG). I consider such cases to be compounds. In (3) the determiners eines/des (M/N.GEN.SG) clearly agree with the genitive attribute Königs, making these cases genitive constructions. In (4) there is either no determiner or the determiner could refer to both nouns, e.g. because the verb gewahr werden 'become aware of' governs the genitive case. I found that such a threefold distinction works best with a quantitative, usage-

5 As in English, separate spelling was possible in ENHG compounds. 
based approach. There are, however, researchers who employ more finegrained, scalar-like systems (Pavlov 1983; Nitta 1987); in any case, all approaches struggle with problems (cf. Ebert 1988: 35).

My study is based on data from three corpora of ENHG and New High German (NHG, since 1650). The Mainz Corpus of (Early) New High German consists of texts from 1500 to 1710 . It is a strongly modified version of the Bergmann \& Nerius (1996) corpus. The corpus is divided into 8 periods, of which 4 are examined here (160,000 tokens). The second corpus used is part of GerManC (Durrell, Ensslin \& Bennett 2007), limited to the subcorpora NEWS, SCIE and SERM in three periods spanning the years 1650 to 1800 (270,000 tokens). For ease of comparison, these periods are marked at 1670,1720 and 1770 in the graphs. The third corpus comprises newspaper texts from 1843 and 1905 taken from the Mannheim Corpus of Historical Newspapers and Magazines, and matches the GerManC's NEWS subcorpus in size $(60,000$ tokens $) .{ }^{6}$

\section{Study 1: Nominal constructions in Early New High German - from genitive attribute to compound}

The diachronic relation between genitive constructions and compounds during and after the genesis of linked compounds has never been investi-

$6 \quad$ To ensure comparability with the Mainz Corpus, which consists of scientific and religious texts in equal shares, SCIE (scientific texts) and SERM (sermons) were chosen from GerManC. The newspaper texts from GerManC (NEWS) and the Mannheim Corpus allow comparison as well. In three graphs (Figure 1, Figure 4 and Figure 8), I combine all data. To justify this, separate analyses for the two groups were carried out first; both showed the same tendencies, the difference in genre did not lead to a difference in the use of compounds, linked compounds or hyphens. 
gated quantitatively. Pavlov (1983) restricts himself to compounds and bridging constructions around 1500 and 1700 . As he collected only types, not tokens for the second period, and as he matched them in number to the types from the first period, his data doesn't allow conclusions pertaining to usage frequency and productivity. Demske (2001), on the other hand, considers corpus data for genitive constructions (in newspapers from 1609 and 1667) but only looks at compounds in a qualitative analysis.

The present study analyzes the interdependence of both types of nominal constructions. As it covers a long time period and considers tokens, it is able to shed light on changes in usage frequency of compounds and seeks to answer the question why they have gained so much in relation to genitive constructions. The frequency of $\mathrm{N}+\mathrm{N}$ compounds increases drastically in the ENHG and NHG period, from 6.2 instances per 1,000 words in 1500 to 34.1 in 1900 (Figure 1). This holds true for unlinked compounds (from 4.5 instances per 1,000 words to 18.2) as well as for compounds with linking elements $-s$ - and $-(e) n$ - (from 1.8 to 15.9). Other linking elements play a marginal role and were therefore excluded. 


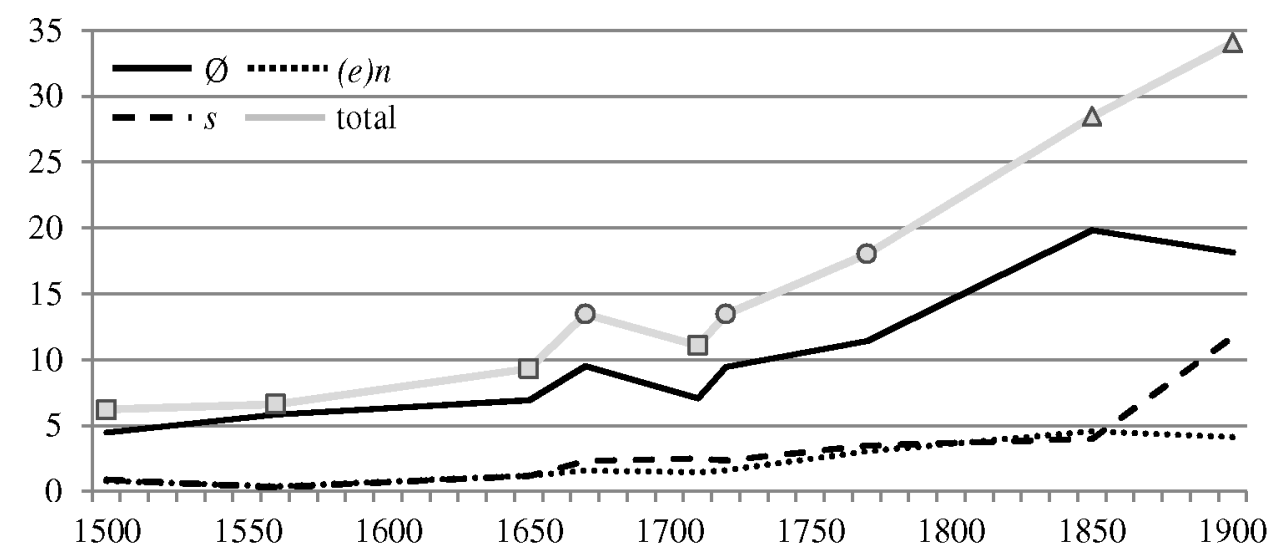

Figure 1. Number of compounds per 1,000 words $(n=7,259)$. (Data combined from Mainz Corpus $\square$, GerManC $\circ$ and Mannheim Newspapers $\triangle.)^{7}$

This change can be partly described as a shift in form: Nouns that were formerly modified by prenominal genitives and maybe, to a lesser degree, by selected adjectives or prepositional phrases (c.f. Table 1), are now modified by an additional morphological constituent. ${ }^{8}$

7 The noticeable stagnation of unlinked compounds in 1900 seems to be counteracted by a strong increase of compounds with linking $-s$-. This could be due to increasing morphological complexity of the input: Compounds whose first constituent ends in a certain suffix (see below) always use linking $-s$ - in present-day German, and prefixed compounds have a strong tendency towards linking $-s$ - (cf. Kopf 2017). Such first constituents make up only 14\% of $s$-linked compounds in 1650-1700 (GerManC NEWS), but 53\% in 1900. At the same time, morphologically complex first constituents are consistently rare in unlinked or $(e) n$-linked compounds (on average $3 \%$ and $1 \%$, respectively). For an evaluation of theories on potential functions of linking $-s$ - in complex compounds see Kopf (2017).

8 There might be other factors at play as well, e.g. replacement of simplex nouns by compounds. The increasing "nominal style" may also be of relevance here; further investigation is needed. 


\begin{tabular}{|c|c|}
\hline a. compound & $\begin{array}{l}\text { die kind-s-geburt } \\
\text { the-NOM.SG child-LE-birth }\end{array}$ \\
\hline $\begin{array}{l}\text { b. genitive } \\
\text { construction }\end{array}$ & $\begin{array}{l}\text { d-es kind-s geburt } \\
\text { the-GEN.SG child-GEN.SG birth } \\
\text { die geburt d-es kind-s } \\
\text { the-NOM.SG birth the-GEN.SG child-GEN.SG }\end{array}$ \\
\hline $\begin{array}{l}\text { c. adjective }+ \\
\text { noun }\end{array}$ & $\begin{array}{l}\text { die kindliche geburt } \\
\text { 'the-NOM.SG infantile birth' }\end{array}$ \\
\hline $\begin{array}{l}\text { d. noun }+ \\
\text { prepositional } \\
\text { phrase }\end{array}$ & $\begin{array}{l}\text { die geburt von d-em kind-e } \\
\text { 'the-NOM.SG birth of the-DAT.SG child- } \\
\text { DAT.SG' }\end{array}$ \\
\hline
\end{tabular}

Although there are OHG (Old High German, 500-1050) and MHG (Middle High German, 1050-1350) examples, reanalysis of genitive constructions truly gained ground in ENHG (Demske 2001: 305). It has been frequently remarked (e.g. Pavlov 1983: 47-48, Demske 2001: 315-316) that not all ENHG genitive constructions lent themselves to such a reanalysis. Apart from the syntactic condition (prenominal genitive attribute), a semantic condition had to be met: Only genitive attributes with non-specific reference can be considered as possible sources, i.e. they are "grammatical synonyms" of compounds (Pavlov 1983: 48, see also 54, 72-78), e.g. der barfiußer regel (genitive), die barfüßerregel (compound) 'the Rule of the Discalced'. This is due to the fact that the first element of a compound does not refer to a specific person, thing or instance (see also Schlücker, this volume): While the child in des kinds geburt can be a certain child in my corpus mostly Jesus - the identity of the child in Kindsgeburt is (even if known) of no relevance and the child cannot be described more 
closely. If we tried this, the adjective would almost always refer to the morphological head, e.g. die schwere Kindsgeburt is a difficult (schwer) childbirth, not the birth of a heavy (schwer) child. ${ }^{9}$

Demske (2001: 315-316) argues similarly that the prenominal position develops a restriction on possessive prenominal genitive attributes while genitives with non-specific semantics either change their position to postnominal (eines Kindes Geburt 'a child's birth' > Geburt eines Kindes 'birth of a child') or are reinterpreted as first constituent of a compound (Kindsgeburt 'childbirth'). However, the restriction on non-specific genitive attributes is less absolute than usually thought: Inherently specific elements like proper names were and still are possible first parts of compounds (die Marien=Kirche 'St. Mary's Church', das schöne Davids Sprïchlein 'the beautiful saying of David', see also Schlücker, this volume). The same holds for name-like common nouns like Gott 'God', one of the earliest cases of reanalysis (e.g. OHG goteshūs 'church (God's house)'), and unique nouns like Sonne 'sun'. Only if these nouns are characterized further, they become unsuitable candidates for compounding: It is very unlikely that des strafenden Gottes Wort 'the word of the punitive God' should be replaced by a compound Gotteswort 'God's word', because strafenden 'punitive' could no longer be read as referring to Gott.

If only the non-specific or inherently specific constructions can be reanalyzed, only they should change over time. To test this, all genitive

9 There are some exceptions in present-day German, e.g. verregnete Feriengefahr 'danger of rainy holidays' instead of 'rainy [danger of holidays]' as suggested by the structure (c.f. Bergmann 1980); these are cases that can be resolved pragmatically. (English, by contrast, employs this pattern of adjectival modification quite frequently, such as in used car dealer, in which the adjective modifies the modifier rather than the head of the compound (cf., e.g., Berg 2011), this is facilitated by its lack of inflectional morphology.) 
constructions and compounds were manually extracted from four time periods of the Mainz Corpus and annotated for both position (post/pre) and specificity:

1. Non-specific: modifying element is unspecified or is inherently specific without further characterization (name-like nouns, unique nouns), e.g. einer Frauen Haus 'house of a woman', die Strafe Gottes 'God's punishment'

2. Specific: modifying element is specified by context, e.g. by an adjective, a demonstrative, possessive or interrogative determiner, a prepositional attribute, a numeral, a relative clause or other sentences, e.g. dieses Mannes Besitz 'this man's possessions', Dort leben drei Schwestern. Das Haus der Schwestern ... 'Three sisters are living there. The sisters' house ...'

The bridging constructions mentioned in (4) above are of special interest because they do not allow a clear distinction in grammatical structure. Pavlov (1983: 73) considers this as "allgemeine Unreife der Opposition von Wortgruppe und Zusammensetzung" ('general immaturity in the opposition of phrase and compound') typical for ENHG. It is, however, not guaranteed that such an ambiguity was indeed present: Written language does not allow us to discern potentially different stress patterns such as can be found today in (des) Váters Brúder, a genitive construction in which both nouns bear main stress vs. (der) Vatersbrùder 'father's brother', a compound with secondary stress on the head noun (cf. Demske 2001: 303).

In light of this, my main hypothesis predicts in particular: 1) The percentage of bridging constructions should be high in the beginning, as 
they are ideal cases for reanalysis, 2) the percentage of non-specific genitive attributes should go down while the percentage of compounds is going up, as the former are replaced - either directly or indirectly - by the latter, and 3) the specific constructions should remain stable because they cannot be substituted by a compound. ${ }^{10}$

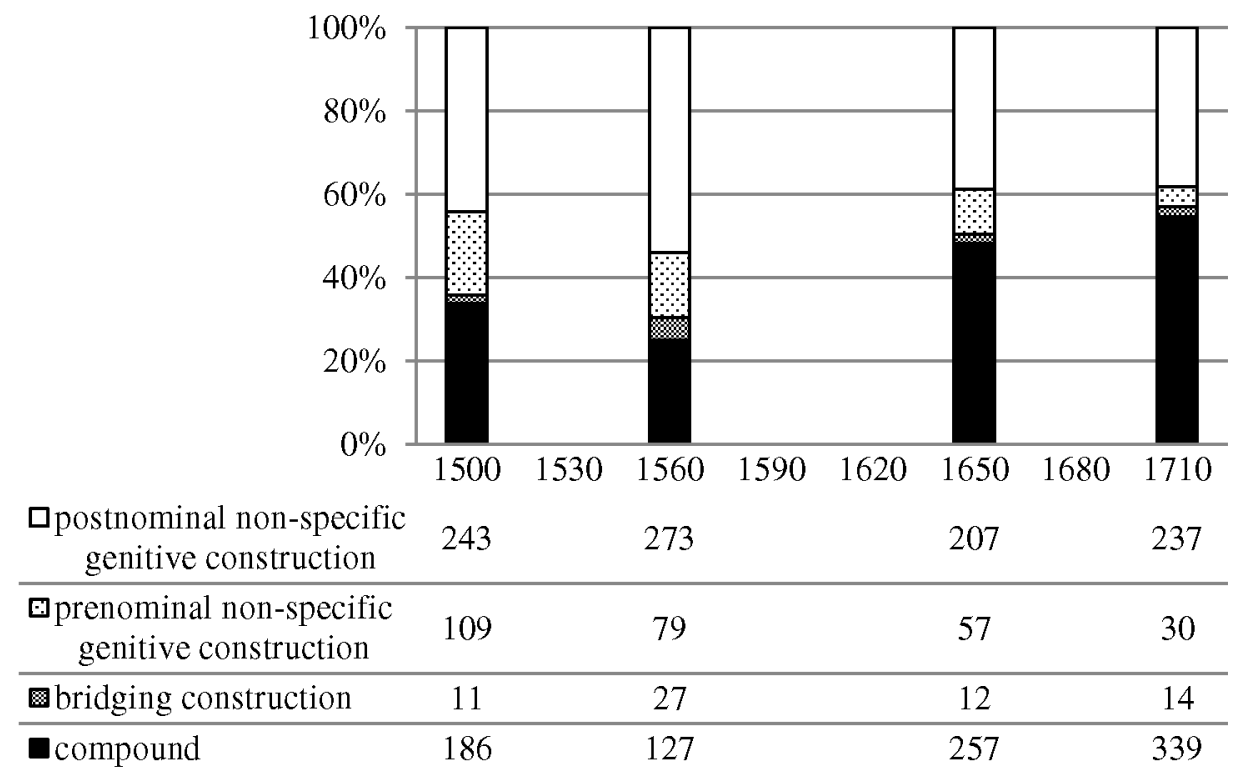

Figure 2. Development of constructions with functional overlap $(n=2,208)$, Mainz Corpus ${ }^{11,12}$

10 Other target domains of the vanishing non-specific genitive attributes were considered, but could not be checked. Following the same logic as in Table 1, non-specific genitives might also be substituted by adjectives (Gottes Wort vs. göttliches Wort) or prepositional phrases. The latter mostly seems to happen when place names are involved and therefore poses no real problem for our data. Only a small number of genitive attributes are semantically suited to a replacement by adjectives, mostly derivatives like königlich 'royal', fürstlich 'princely', göttlich 'divine', gnädig 'merciful'. A small amount of texts from 1500 and 1710 was checked for such adjectives and no increase could be discerned.

11 Compounds without linking elements were excluded if their first constituent showed an overt genitive suffix when used independently (e.g. Abend-essen, but des Abends). Of course, sometimes genitives were not 
My analysis yields the following results (cf. Figure 2): As expected, the proportion of prenominal non-specific genitive attributes declines while the proportion of compounds increases. To test that the declining proportion of the prenominal cases is not due to the positional shift of genitive attributes, the postnominal non-specific cases were checked as well. As they are declining, too, it is highly implausible that the vanishing nonspecific prenominal constructions are simply postposed - postnominal non-specific genitives might even be exchanged for compounds as well as the pattern becomes more widespread. A $\chi^{2}$ test shows that the differences reported in Figure 2 are highly significant $(\mathrm{p}<.001)$ albeit with a relatively small effect size (Cramer's V: .157). Table 2 reports Pearson residuals, measuring how strongly the observed value of a cell differs from its expected value. ${ }^{13}$ Overall the residuals confirm what can be seen in Figure 2: Compounds are lower in the 16th century than in the 17th while the reverse is the case for genitives, especially when prenominal. The somewhat larger differences in 1560 remain to be explained, but are not due to a single text. Bridging constructions remain rare throughout. Their number may be irrelevant for reanalysis, they might not have been truly ambiguous (due to stress patterns), or the written corpora are a poor reflection of ENHG as such.

overtly marked on the attribute, therefore some unlinked compounds might still be the results of reanalysis. My data suggests, however, that these cases are marginal.

$12 \quad \chi^{2}=164.08, \mathrm{df}=9, \mathrm{p}<.001$, Cramer's V: .157

13 Pearson residuals are unsquared $\chi^{2}$ components. Values exceeding 2 show that the observed value is higher than expected at a statistically significant level, values below -2 show, that the observed value is lower than expected. 


\begin{tabular}{|c|c|c|c|c|}
\hline & compound & $\begin{array}{l}\text { bridging } \\
\text { construction }\end{array}$ & $\begin{array}{l}\text { prenominal } \\
\text { non-specific }\end{array}$ & $\begin{array}{l}\text { postnominal } \\
\text { e construction }\end{array}$ \\
\hline 1500 & -2.66 & -1.23 & 4.91 & 0.28 \\
\hline 1560 & -5.63 & 3.22 & 2.01 & 3.57 \\
\hline 1650 & 2.54 & -0.88 & -1.15 & -1.63 \\
\hline 1710 & 5.24 & -0.94 & -5.37 & -1.98 \\
\hline
\end{tabular}

Table 2. Pearson residuals for constructions with functional overlap $(\mathrm{n}=$ 2,208), Mainz Corpus

There is little change in the (low) number of prenominal specific genitives and erratic fluctuation in the postnominal cases, ${ }^{14}$ hence it doesn't seem to be the case that noun phrases involving genitive attributes are becoming more specific.

14 These cases are not included in the graph because it shows the relation between the candidates for reanalysis or functional substitution on1y. As percentages are used, the addition of unrelated material would blur the picture. The numbers are as follows (percentages given in relation to all constructions in the corpus):

\begin{tabular}{lll}
\hline & postnominal specific & prenominal specific \\
\hline $\mathbf{1 5 0 0}$ & $262(30 \%)$ & $71(8 \%)$ \\
\hline $\mathbf{1 5 6 0}$ & $159(23 \%)$ & $40(6 \%)$ \\
\hline $\mathbf{1 6 5 0}$ & $148(20 \%)$ & $45(6 \%)$ \\
\hline $\mathbf{1 7 1 0}$ & $291(31 \%)$ & $38(4 \%)$ \\
\hline
\end{tabular}

The "disappearing" non-specific genitives should lead to an increase of specific genitives, if it was the case that non-specific genitive phrases became altogether more specific instead of being partly replaced by compounds, or to a decrease if there was an overarching development towards less specificity. (Both scenarios also seem somewhat implausible, as specific and non-specific use are governed by the fact that speakers sometimes want to talk about something in general and at other times about a certain person, thing or instance - the two are not generally interchangeable for the purpose of communication.) 
Linear regressions for time and construction type show that compounds are not increasing at the same rate as genitives are decreasing, cf. Figure 3 . This suggests that additional factors are at play, furthering the use of compounds in written ENHG, cf. fn. 8.

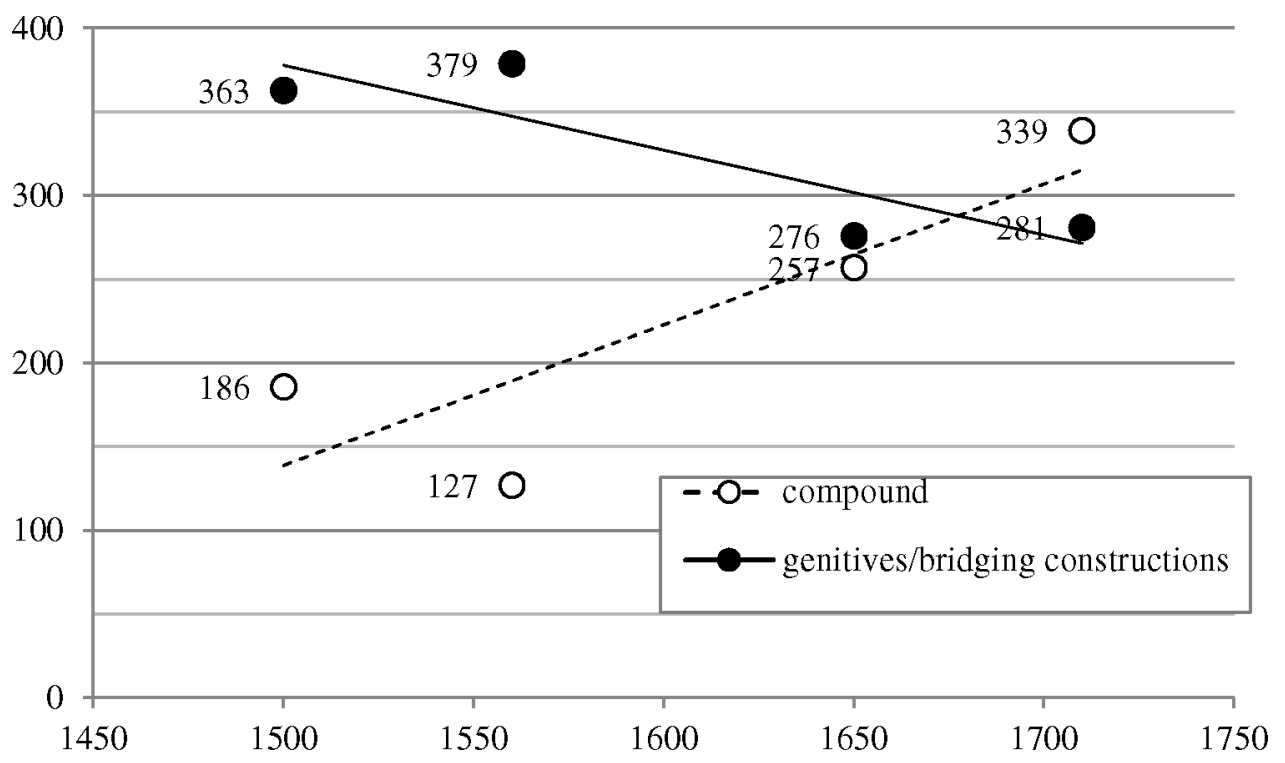

Figure 3. Linear regressions on data from Figure 2 (Compounds: $y=$ $0.8397 x-1120.4, R^{2}=.73$; all other constructions: $y=-0.5075 x+$ $\left.1139.2, \mathrm{R}^{2}=.77\right)$

In conclusion, I tentatively assume a shift in expression for nominal elements with non-specific semantics that modify a second noun: In 1500 most of these cases are expressed with genitive constructions, by 1710 compounds make up the majority.

\section{Study 2: Measuring productivity of compounding patterns}

The productivity of compounding in present-day German is often casually subsumed under discussions of derivational morphology, cf. "all the dis- 
cussion here should equally apply to compounds" (Bauer 2005: 316). It is a highly productive word formation process with very few restrictions. In OHG, compounds of more than two nouns existed but were more uncommon than today and often contained a strongly lexicalized compound (e.g. buochstap in buoch-stap-zīla 'book stick row (= row of letters)'). Derived constituents were unusual, especially if the word formation suffix was still productive (cf. Henzen ${ }^{2}$ 1957: 47-48). In present-day German, such input restrictions are almost nonexistent (cf. Wurzel 1996: 504). This might explain why productivity in German compounding receives so little attention from researchers. However, if we add linking elements to the mix, productivity becomes a very useful concept: The new compounding type from former genitive constructions must of course have developed and expanded in productivity, so that a comparison with the unlinked pattern will be instructive.

Most research on linking elements calls the linking elements themselves "productive" and "unproductive" (Fuhrhop 1998: 194-196; Kürschner 2003: 45; Nübling \& Szczepaniak 2008). I avoid this abbreviated way of speaking because it complicates the comparison with unlinked compounds: As these make no use of linking elements, their productivity could only be measured for the whole compounding pattern. Thus productivity will be investigated for linked compounds $(\mathrm{N}+\mathrm{LE}+\mathrm{N})$ and unlinked compounds $(\mathrm{N}+\mathrm{N}) .{ }^{15}$

15 Schlücker (2012: 6) considers the two types (N+N and N+LE+N) in present-day German as formal variation of a uniform word formation pattern, because the linking elements add no semantic value to the word formation product. However, she assumes that this once was the case, before unparadigmatic use developed, because the (former) genitive case could still be interpreted as such. For the scope of this paper, it isn't relevant whether I speak of formal variants or different compounding types, for the sake of terminological simplicity I will stick with the latter. 
To determine productivity of linked compounds in the early stages, two approaches were chosen in the present study: 1.) The first focuses on restrictions on first constituents, 2.) the second calculates $P$, productivity in the narrow sense according to Baayen (1992).

1.) The pattern of linked compounds had to lose restrictions established by the linking elements themselves, imposed by the former inflectional class: In the beginning, they occurred only where they were "paradigmatic", i.e. where a genitive form identical to the first constituent existed - this is a natural consequence of their genesis in univerbation. Later on, the pattern using - $s$ - accepted other nouns as well: Cases like Arbeit-shaus 'work house' cannot be a direct product of reanalysis from a former genitive as $-s$ never occurs as genitive marker for feminine nouns (with the exception of proper names). I therefore extracted all compounds with linking $-s$ - from the corpora and divided them into a paradigmatic and an unparadigmatic group. Figure 4 shows the relation between the two. A clear trend can be discerned: While the corpus showed no unparadigmatic cases in 1500 and $1560,{ }^{16}$ they rise to $26 \%$ in 1650 and reach $43 \%$ by 1900. At the end of my time span, they strongly adhere to nouns derived by a select number of suffixes (-ung, -ion, -schaft, -heit/keit, -tum, -ität, ling, -sal, cf. Aronoff \& Fuhrhop 2002: 61; Nübling \& Szczepaniak 2008: 20). This is not the case in earlier stages, where much variation is exhibited, e.g. Appellation-rat but Konfession-s-übung. ${ }^{17}$

16 Earlier cases exist, but were so few that none of them are attested in my corpus.

17 Unparadigmatic cases in linked compounds using - (e)n- are much rarer. They are mostly relicts of old inflectional suffixes (Demske 1999: 159; Nübling \& Szczepaniak 2008: 5): Hahnenkamm 'cockscomb' is based on the earlier genitive Hahnen, today's genitive is Hahns. An analysis of such cases would only determine the point in time when the noun changed its inflectional class and therefore be useless for measuring 


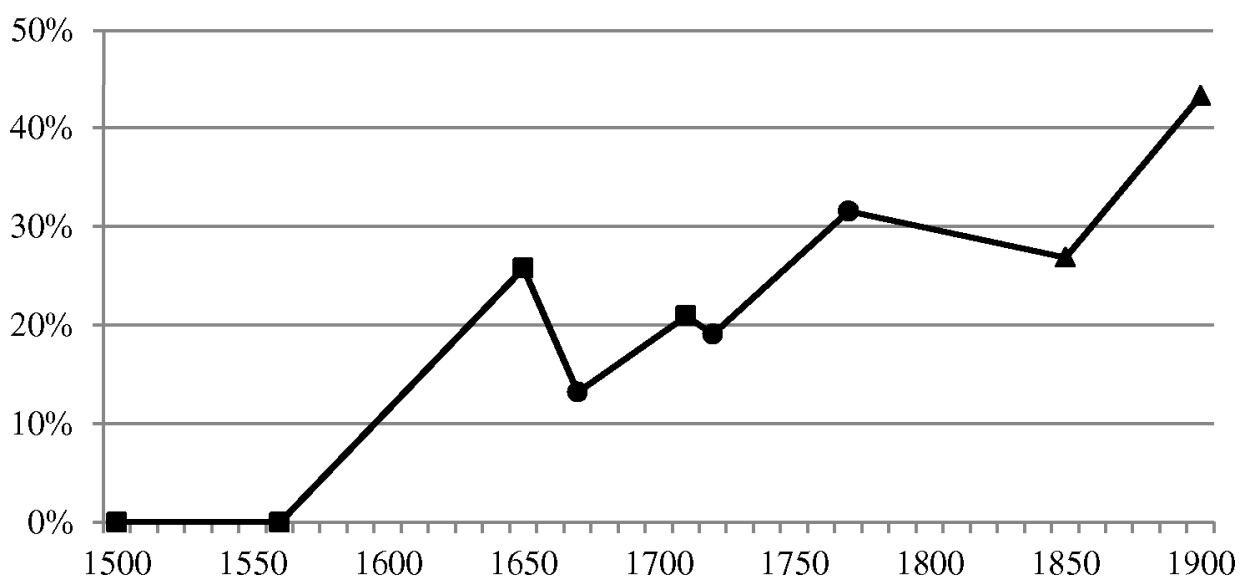

Figure 4. Percentage of unparadigmatic linking $-s$ - in relation to all compounds with linking $-s-(\mathrm{n}=1,659)^{18,19}$

I consider these numbers conclusively evidencing a new, productive compounding pattern from 1650 at the latest, but due to the relatively small corpus, the growth is much more interesting than the precise onset date.

productivity in compounding. There are, however, some exceptions for compounds with -en-: It is used unparadigmatically in Latinate loans like Instrument-en-klang 'sound of (an) instrument(s)', Medikament-enpackung 'medicine box' and exerts complex restrictions on the first constituent (cf. Klein 2015).

18 Due to different corpus sizes, productivity in the narrow sense could not be employed in this case.

19 Data combined from Mainz Corpus $\bullet$, GerManC $\bullet$ and Mannheim Newspapers $\boldsymbol{\Delta}$. 


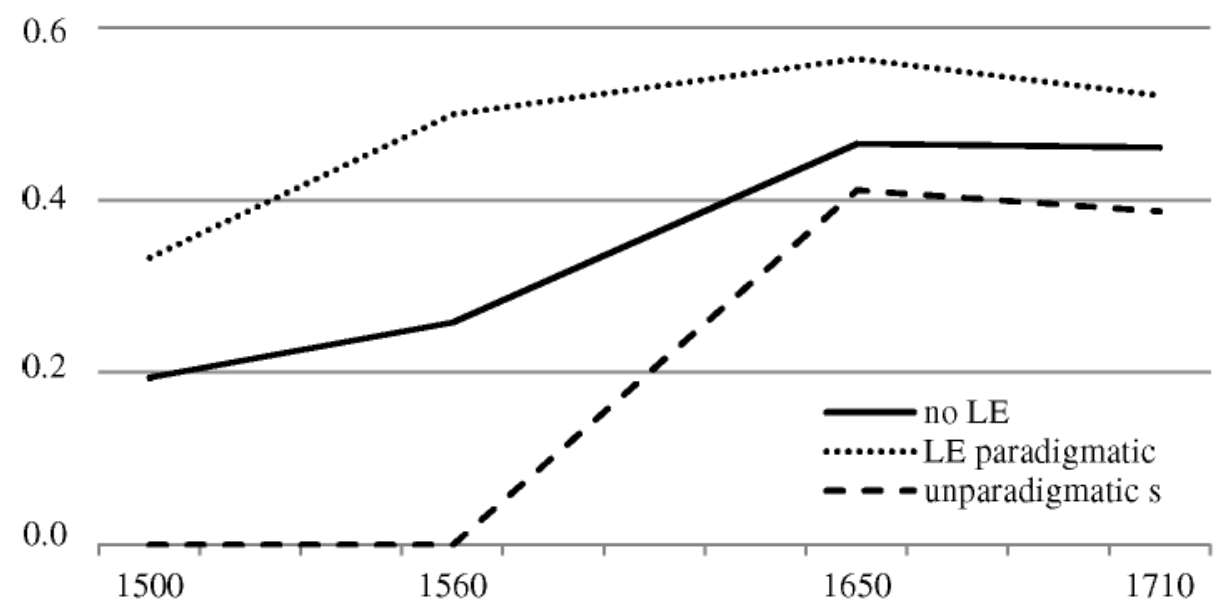

Figure 5. Productivity in the narrow sense (tokens $=1,534$; hapax legomena: 592), Mainz Corpus

2.) Productivity in the narrow sense, also termed potential productivity (Baayen 2009), was measured according to Baayen (1992: 115-119) by calculating all tokens and hapax legomena following a certain compounding pattern. The values for unparadigmatic $-s$ - for example are the quotients of all hapax legomena containing unparadigmatic linking $-s$ - found in the period analyzed divided by all compound tokens containing unparadigmatic linking $-s$ - in the same period (Figure 5). The resulting value $P$ "express[es] the statistical readiness with which new formations are encountered" (Baayen 1992: 115). As the number of text words must be equal in all periods compared, only the Mainz Corpus was used.

If the linked pattern makes use of paradigmatic elements, the numbers start off at a relatively high level $(0.33)$ - as is to be expected, because all cases of reanalysis are contained in this group. The linked compounds using unparadigmatic $-s$ - were calculated separately: As can be seen, they appeared later and their productivity rose from zero to 0.41 in 1650. This should, however, be taken with a grain of salt as the total numbers are very small (48 tokens, 19 hapaxes for 1650-1710). Compounds 
without linking elements, while remaining below the linked compounds, become more productive as well. This might reflect the loss of input restrictions. In the second half of the time period investigated, the differences between the three types are much smaller. All numbers must be interpreted very carefully, as the corpus is relatively small. This yields many hapaxes that are not truly new, but were simply not previously attested by chance (cf. Baayen 2009: 905). If combined with other data, e.g. the reduced restrictions on compounding, the growing percentage of unparadigmaticly linked compounds and the situation in present-day German (see below), it is still instructive.

The available data for NHG unfortunately doesn't lend itself to quantitative productivity measures at all, therefore direct comparison with the corpus data presented here is impossible: The studies are synchronic in nature and comprise only types (Kürschner 2003) or even only types that were first attested at the time of compilation (own study, see below). Nübling \& Sczcepaniak (2011) make use of doubtful cases like Seminararbeit/Seminar-s-arbeit 'term paper', they only show diachronic variation in the 20 th century (using the DWDS main corpus) in a very small number of cases. It remains to be determined how meaningful these are. While both $-s$ - and $-(e) n$ - are found in about $39 \%$ of compound types in newspapers (Kürschner 2003: 105 and own data), most of them combine almost exclusively with first elements that established linking elements centuries ago, e.g. Arbeits- (DTA, 1631) (on similar aspects see Fuhrhop 1998: 195), and especially with the aforementioned derivatives ending in -ung, -ion etc. As the latter are morphological heads that almost exclusively link with -s-, they should not be considered evidence of productivity. If we discount these formations and consider only recent loans as first constituents, linked compounds are reduced to $5 \%(1 \% s, 4 \%(e) n)$ (own analysis 
of data from Wortwarte 2009/2010, $n=292$ ). This is even true for new loans that are identical in phonological structure (stress pattern, number of syllables, final consonant) to older first constituents: Desígn(-philosophie) 'design philosophy' - Vereín(-s-philosophie) 'club philosophy', Entertáinment(-erwartung) 'expectation of entertainment'- Kultiviertheit(-serwartung) 'expectation of sophistication'. On this basis, I tentatively conclude that the prevalence of linking elements in present-day German is high but the productivity of the pattern is rather low.

\section{Study 3: Persisting syntactic properties}

As mentioned earlier, for the scope of this paper compounds are defined by grammatical properties only. I excluded spelling practice (i.e. spaces, hyphenation) as criterion, unlike Pavlov (1983: 19-20), who considers it additional evidence. My data shows that compound writing was not established in late ENHG (1500-1650) and early NHG (1650-1800): ${ }^{20}$ Even compounds that are attested in the OHG or MHG period without linking elements are sometimes written separately, e.g. <nott sachen> 'urgent affair(s)', <hochtzeit tag > 'holiday, wedding day' (see Figure 6). ${ }^{21}$ Although the writing of compounds should not make them compounds as such, a graphematical analysis can inform our understanding of how the new compound type fits into the grammatical system.

20 For the purpose of this paper, only the second half of the ENHG period is considered in the corpus data ("late ENHG"). The term "early NHG" refers roughly to the years 1650-1800, the beginning of the New High German period.

21 Spelling practice is especially problematic if the nouns are written separately. If they are written as one word, there are much fewer cases that can be shown to be genitive constructions, see also Nitta (1987: 406). 
As Figure 6 shows, unlinked compounds do make use of separate writing, but only rarely ( $13 \%$ at the most), while linked compounds are written separately in $78 \%$ of all cases at the beginning of the time frame investigated. This percentage strongly declines over the course of the next 200 years; in 1710 only $7 \%$ are remaining. Writing practice for these new compounds lags behind their grammatical integration, it reflects their syntactic origins. As they leave the latter increasingly behind, e.g. by transferring the linking element $-s$ - to feminine nouns, linked compounds adopt the established compound spelling.

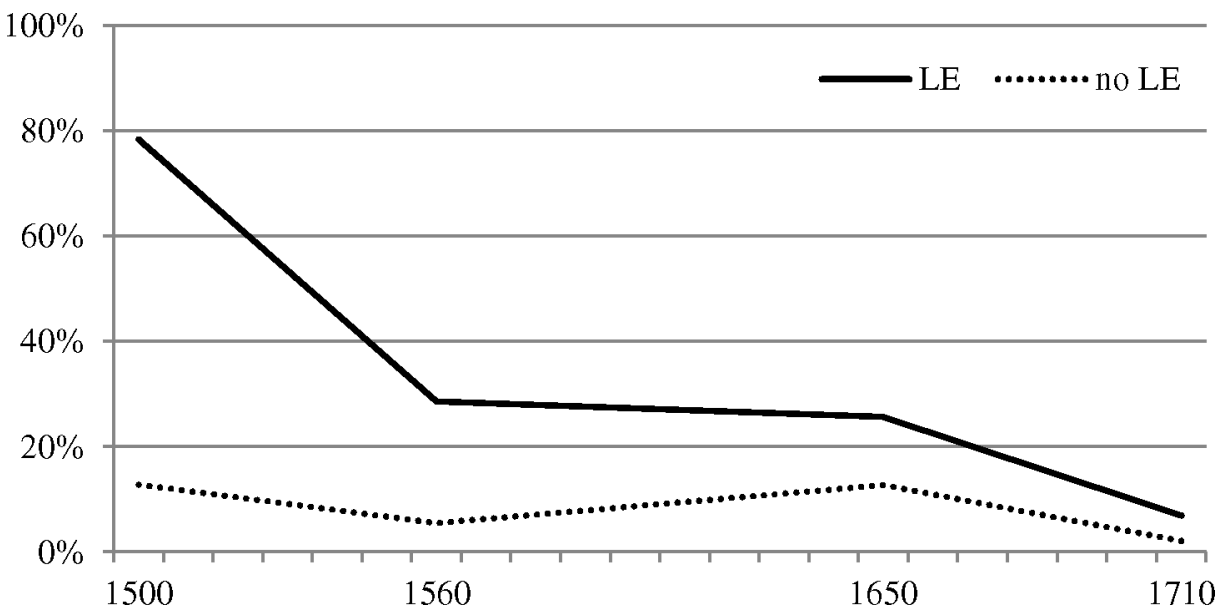

Figure 6. Percentage of compounds that are written with a space $(n=$ 1,402), Mainz Corpus

This is, however, not the whole story: At the beginning of the 17th century, a new spelling strategy - hyphenation - developed. Its relation with separate writing is peculiar: While separate forms are found with almost the same percentage as 90 years before, hyphenated spellings undo the graphematical integration process - they marginalize directly connected 
spelling (i.e. spelling without any intervening non-letters at the inner boundary) in linked compounds (Figure 7).

- directly connected (Leibserben)

$\boldsymbol{D}$ connected by hyphen (Leibs-Erben)

$\square$ unconnected (Leibs Erben)

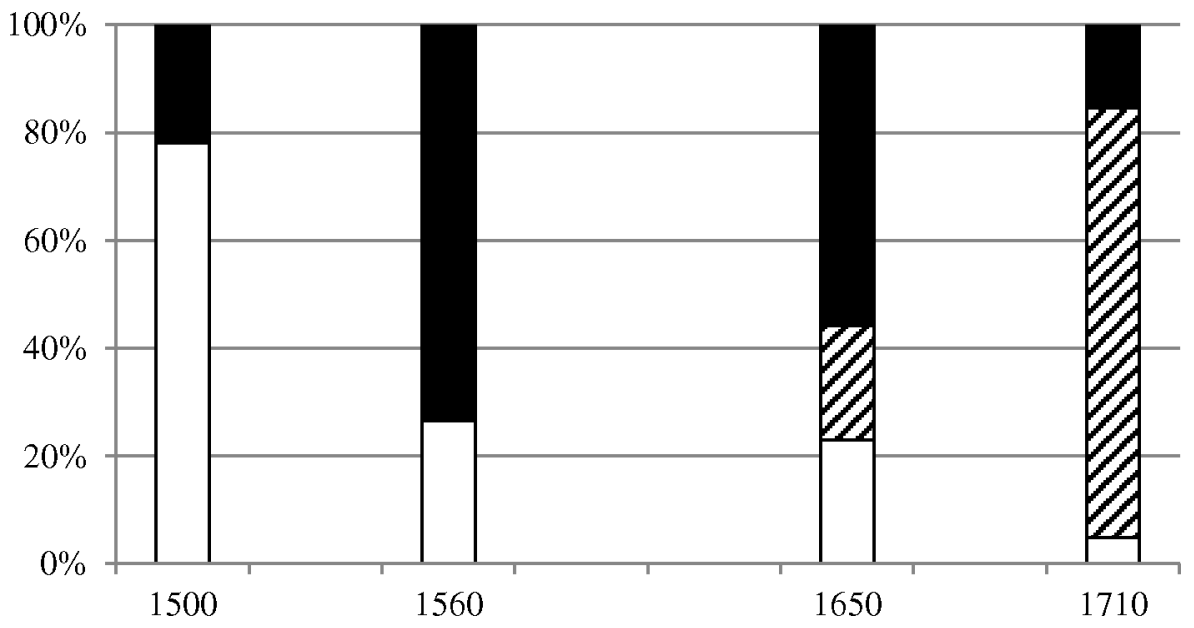

Figure 7. Spelling of compounds with linking elements $(n=431)$, Mainz Corpus

Hyphenation in early NHG was restricted almost exclusively to $\mathrm{N}+\mathrm{N}$ compounds. At the point of its maximal diffusion, in the first half of the 18 th century, up to $72 \%$ of all nominal compounds were separated by hyphens; other parts of speech show hyphenation at a maximum of $0.5 \%$. The phenomenon was, however, short-lived: In the second half of the 18th century it was down to $8 \%$ and at the beginning of the 20 th century only $1 \%$ of all $\mathrm{N}+\mathrm{N}$ compounds were hyphenated (see Figure 8) (cf. Kopf 2017).

A separate analysis of linked and unlinked compounds shows an interesting distribution: In present-day German, hyphenation (which is rare anyways) is usually suppressed when a linking element occurs (cf. 
Grube 1976; Borgwaldt 2013; Kopf 2017). The opposite is the case for 17th century German. Solling (2012: 125-151) analyzed sermons from 1550 to 1710 and found striking differences between the two types of compounds. Unlinked compounds made consistently rare use of separate spelling. Meanwhile, linked compounds show diachronic change: Separate spelling steadily declines. Hyphenation first occurs in 1600 and 1620 in two single instances; it is noticeable from 1660 and increases in 1710 for all compounds. Those with linking elements, however, show a much higher hyphenation rate.

My data paints a similar picture for a much larger time frame (Figure 8). Hyphenation reaches about $90 \%$ for linked compounds with no difference between linking elements while it remains at max. 64\% for unlinked compounds. This establishes a clear preference for hyphenation in linked compounds from around 1650 to 1750.

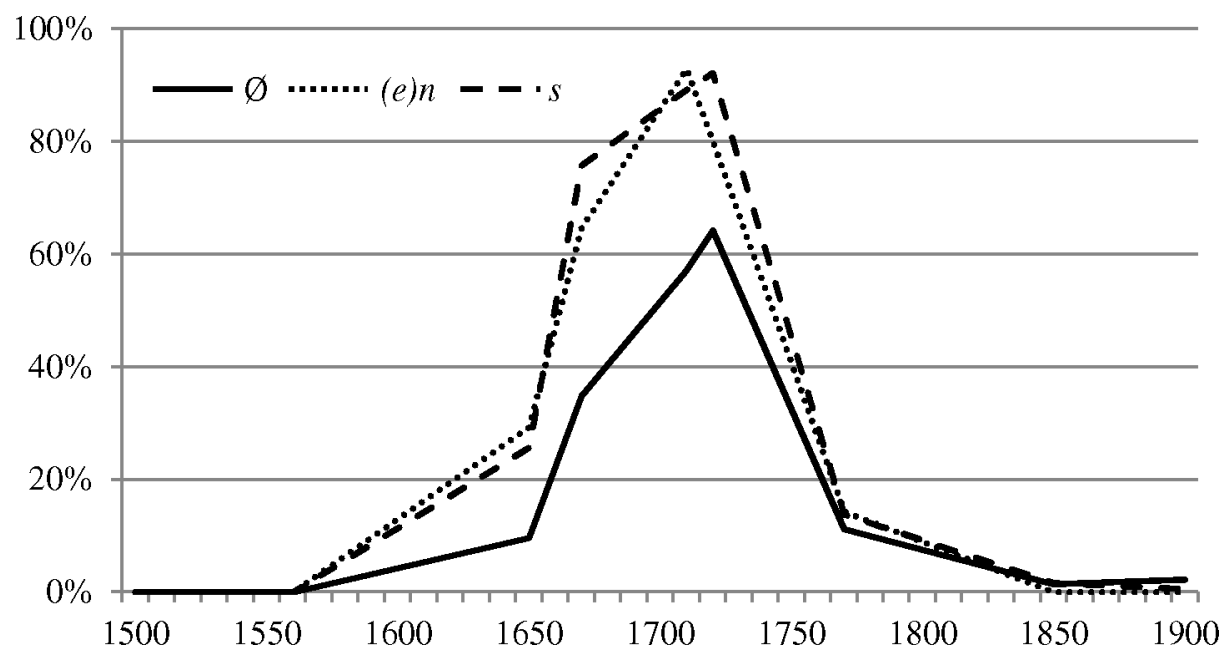

Figure 8. Hyphenation rate in $\mathrm{N}+\mathrm{N}$ compounds depending on linking elements $(\mathrm{n}=7,435)$. (Data combined from Mainz Corpus, GerManC and Mannheim Newspapers) 
This is confirmed by contemporary grammarian Bödiker (1701: 36):

Ob man die Composita substantiva auch in der Mitte so zeichnen soll? Es scheinet wol fast ohne Noht; Jst auch wegen der unsäglichen Menge solcher Compositorum unmüglich. Doch aber in Wörtern/ die etwas dunkel und schwer zusammen gesetzet/ oder wo das erste Nomen im Genitivo stehet/ oder da sonst fremde mercksame Wort zusammen kommen/ ist es fast nöhtig. (original emphasis)

'Should we mark compound nouns like this in the middle? It seems almost unnecessary and it is impossible due to the sheer number of compounds. But it is almost necessary in words that are combined in an intransparent way, or where the first noun has genitive form or if otherwise unusual words are combined.' (my translation, $\mathrm{KK}$ )

In present-day German, hyphenation plays a marginal role at best. I calculated a hyphenation rate of only 7\% in compounds from 1966-1973 from Grube's (1976) corpus data (which is made up of newspapers, magazines, scientific literature and fictional prose). Hyphenation is restricted to word formation products with at least one marked constituent (e.g. loan words, abbreviations, quotes, proper names or words containing unusual characters such as numbers), to cases in which the beginning of the second element cannot be easily discerned due to an initial vowel grapheme (e.g. $<$ Druck-Erzeugnis $>$ 'print product' vs. <Drucker-Zeugnis $>$ 'printer's certificate') ${ }^{22}$ or to compounds containing three or more nouns (cf. Bredel

22 As vowel-initial nouns are today preceded by a glottal stop, this segmentation problem has no correlate in spoken German. 
2008; Buchmann 2015; Kopf 2017; Schlücker, this volume). In all these cases it serves as a segmentation aid, as can also be seen from the official spelling rules (DR 2011: 45):

Der Bindestrich bietet dem Schreibenden die Möglichkeit, [...] die einzelnen Bestandteile als solche zu kennzeichnen, sie gegeneinander abzusetzen und sie dadurch für den Lesenden hervorzuheben.

'The hyphen allows the writer [...] to mark the single components as such, to define them from one another and by doing so to emphasize them for the reader.' (my translation, KK)

Non-standard spelling makes use of hyphenation also by breaking up smaller morphological units; this comes closer to early NHG use. Scherer (2012) considers spellings like $<$ Reise-Zentrum $>$ 'travel center' (instead of $<$ Reisezentrum $>$ ) as reader-oriented reduction of complex structures potentially comparable to the compound stress pattern in spoken language. It remains to be shown whether such cases are a continuation of earlier use that was displaced from standard texts or a development in its own right.

In light of the clear differences between today's usage in published texts and that of earlier centuries, it seems warranted to ask if hyphenation serves comparable functions: Today, prevalence of hyphenated spellings is low and even lower in compounds with linking elements. Between 1650 and 1750, hyphenated spellings were very frequent and even more frequent in compounds with linking elements (see Table 3). 


\begin{tabular}{lll}
\hline & $\mathbf{1 7 0 0 - 1 7 5 0}$ & $\mathbf{1 9 6 6 - 1 9 7 3}$ \\
\hline LE & $87 \%$ & $3.0 \%$ \\
no LE & $64 \%$ & $9.2 \%$ \\
\hline
\end{tabular}

Table 3. Quantitative differences in hyphenation of $\mathrm{N}+\mathrm{N}$ compounds between 18 th and 20th century $(n=1,289$, GerManC; 5,332 , Grube 1976)

Today, we consider linked compounds as inseparable precisely because they contain linking elements, cf. Heller (2000: 27):

Und wenn der Bindestrich sogar gesetzt wird, wenn ein Fugenelement die Zusammenschreibung verlangt, wird das Gliedern zur bloßen Manie.

'And if a hyphen is even used when a linking element demands writing the word as a closed compound, segmentation becomes pure mania.' (my translation, KK)

This may be due to the fact that linking elements enhance the structure of the first constituent so that its phonology becomes more prototypical: In most cases, $-(e) n$ - forms or retains trochees and therefore creates elements that follow a stress pattern typical for present-day German (Wegener 2003: 446-447). For -s-, the case is not so clear, but it often attaches to first constituents ending in a plosive (and never in vowels), so it creates consonant clusters which contain extrasyllabic elements in many cases. These are typical for word boundaries in present-day German (Nübling \& Sczepaniak 2008: 15-16). The linking element serves as a segmentation aid in itself and linked compounds are in no need of further, purely graphematical markers. 
This seems not to have been the case in early NHG. One of the first grammarians to mention hyphenation in complex words is Schottel (1663: 674-675), shortly after it first occurs in my corpus. ${ }^{23}$ In reference to compounds (including compounds with adjectives as one or both constituents) he asserts:

[...] daß zwei/ etwas sonderlichs bedeutende Wörter/ durch das Mittelstrichlein werden aneinander gefügt/ damit der Leser also den Zusammenstand des Verstandes deroselben vernehmen/ und nach dem letzten/als hierin dem Grundworte/ die Meinung hauptsächlich richte: Denn das vorderst oder beifügige Wort/ allemahl das letztere Wort gleichsam erkläret.

'[...] that two words with distinct meanings are combined by a hyphen ("middle-dash") so that the reader may understand the combination of their meaning while determining the main sense from the second word: The first or accompanying word explains the second word.' (my translation, KK)

This suggests that, like today, the hyphen is employed as segmentation aid - but on a much larger scale and in different cases: Segmentation seems to have been hindered especially in linked compounds. I assume that this compounding pattern was still marked in early NHG time and that marked forms were made more explicit by hyphenation (as they are today in case

23 The hyphen in this function first developed during the 16th century. The earliest attestations in German texts found in an unsystematic search (in book titles listed in VD 16) are from 1590, <Jahrs=Tag $>$ 'anniversary (year's day)', <Gnaden=Wundern $>$ 'miracles of mercy' (VD16 P 4640). (The Bonn ENHG Corpus, which ranges from 1350 to 1700 and therefore could include earlier uses, shows hyphens from 1650 onwards only.) 
of abbreviations, names and the like). This is supported by Bödiker's (1701: 36) enumeration which includes other marked cases, namely "intransparent" combinations and "unusual/strange" words.

The use of hyphens in linked compounds shows their connection to syntax as well as their transition to word formation (see also Solling 2012: 286). As unparadigmatic linking elements have spread before the heyday of hyphenation, I assume that hyphenation is not an indicator of unclear categorical status. This is supported by the fact that hyphens occur in a large number of unlinked compounds as well (see Figure 8 above). ${ }^{24}$ It remains unclear why hyphenation caught on relatively late. Solling (2012: 292) assumes that at that time spelling of linked compounds was not fixed yet, which is why hyphenation could gain hold. One could also assume that hyphenation was employed to distinguish linked compounds from syntactic structures. However, the data shows that separate writing had mostly become uncommon when hyphenation began to spread; Solling (2012: 295) points this out as well. ${ }^{25}$ By 1800 , hyphenation in compounds fell out of use. This indicates that the new compounding pattern was omnipresent in usage and had become an unmarked means of word formation.

24 These are probably influenced by linked compounds (cf. Solling 2012: 291-292).

25 Solling (2012: 287-292) speculates that the basis of hyphenation in German was French spelling practice in the second half of the 16th century. However, the French hyphen was not employed to mark nominal compounds; these were uncommon at the time (Solling 2012: 288). He fails to show parallels in function that exceed simple presence of a sign at roughly the same time. As reason for the spread, he considers awareness of morphological structure, proof of which he sees in the "Stammwörter" ('stem words') concept popular at the time (Solling 2012: 288-292). This seems a rather weak argument to me: Hyphenation is not found in all cases of morphologically complex words and linked compounds are not hyphenated in such a way that the stem of the first constituent is exposed. 


\section{Summary and conclusion}

The present studies shed light on the genesis and spread of a new compounding pattern with linking elements in (E)NHG, using comprehensive corpus data that allows to consider the interplay of syntax and morphology.

Study 1 showed how reanalysis and replacement of non-specific genitive constructions are reflected in quantitative data: The percentage of compounds grows steadily from 1500 to 1710 while non-specific genitive constructions recede. As this is also the case for postnominal non-specific genitives, we are witnessing not just simple cases of reanalysis. Genitive constructions are substituted by compounds even if the sequence of elements is not identical, the semantics are retained, but the form is altered. A prerequisite for such substitutions is the existence of the new pattern to coin linked compounds.

This new compounding pattern can also be shown by measuring productivity, as was done in study 2 . A period of higher productivity in early NHG is suggested by two measures: From 1500 to 1710 the probability of new formations with paradigmatic linking elements surpasses that of unlinked compounds. Also, the rise of compounds with unparadigmatic linking $-s$ - is evidence of their now purely morphological origin. Their usage frequency is still high in present-day German, but linking $-s$ - almost only spreads to new compounds when its first constituent has used it before; it is at best marginally productive with loans.

Even though linking elements separated early on from the inflectional suffixes that once were their source, they adhere to a different 
spelling practice, shown in study 3 . While in the first half of the 18 th century, linked compounds are hyphenated in most of the cases, the rate is much lower for unlinked compounds. As separate writing had already fallen out of use for linked compounds, spelling must reflect a synchronically perceived markedness of these forms, not an earlier unclear categorical status. The high hyphenation rate ends a mere 100 years after the first attestation of unparadigmatic linking elements in my corpus, at this point in time the pattern seems to be fully integrated in German morphology, writers therefore cease to separate the formerly marked first constituents with linking elements graphematically. In present-day German, writers usually refrain from hyphenation when spelling linked compounds: Linking elements are an integral part of the first constituent; they usually improve or maintain the prototypical phonological structure of German words. At the same time, constituents that are synchronically marked because they do not conform to speakers' expectations (e.g. loans, abbreviations, names) still use hyphens to expose the morphological structure of their compounds.

Overall, we can observe that the shift from syntax to wordformation did not occur abruptly: The new pattern gradually developed and found its way into the core of the morphological system over several centuries, reaching most of its present-day status by about 1900 .

\section{Corpora}

GerManC. Manchester University, Martin Durrell et al. Three genres (SCIE, SERM, NEWS) à 90,000 tokens used. 
Mainz Corpus of (Early) New High German. Mainz University, Kristin Kopf, 2010-2013. Four of eight time periods used, 160,000 tokens.

Mannheim Corpus of Historical Newspapers and Magazines. Institut für Deutsche Sprache, 2013. Access to full texts via: $<$ http://hdl.handle.net/10932/00-01B8-AE41-41A4-DC01-5>.

Excerpts of 30,000 tokens from the following newspapers were used: Das Pfennig=Magazin für Belehrung und Unterhaltung, Nr. 9 (1943); EUROPA Wochenschrift für Kultur und Politik (1905).

VD 16. Verzeichnis der im deutschen Sprachbereich erschienenen Drucke des 16 . Jahrhunderts. [Inventory of prints from the $16^{\text {th }}$ century that have been published in the German language area.] Bayerische Staatsbibliothek. Access via $<$ www.gatewaybayern.de/index_vd16.html>.

Wortwarte. Lothar Lemnitzer, Berlin-Brandenburgische Akademie der Wissenschaften, 2000-2015. Access via <www.wortwarte.de $>$.

\section{References}

Aronoff, Mark \& Nanna Fuhrhop. 2002. Restricting suffix combinations in German and English: Closing suffixes and the monosuffix constraint. Natural Language \& Linguistic Theory 20: 451-490.

Baayen, Harald. 1992. Quantitative aspects of morphological productivity. In Yearbook of Morphology 1991, Geert E. Booij \& Jaap van Marle (eds), 109-149. Dordrecht: Kluwer.

Baayen, R. Harald. 2009. Corpus linguistics in morphology: Morphological productivity. In Corpus linguistics [Handbücher zur Sprach- und Kommunikationswissenschaft/Handbooks of Linguistics and Com- 
munication Science (HSK) 29/2], Anke Lüdeling \& Merja Kytö (eds), 899-919. Berlin \& New York: de Gruyter.

Bauer, Laurie. 2005. Productivity: theories. In Handbook of WordFormation, Pavol Štekauer \& Rochelle Lieber (eds), 315-334. Dordrecht: Springer.

Berg, Thomas. 2011. The modification of compounds by attributive adjectives. Language Sciences 33: 725-737.

Bergmann, Rolf. 1980. Verregnete Feriengefahr und Deutsche Sprachwissenschaft. Zum Verhältnis von Substantivkompositum und Adjektivattribut. Sprachwissenschaft 5: 234-265.

Bergmann, Rolf \& Dieter Nerius (eds). 1996. Die Entwicklung der Großschreibung im Deutschen von 1500 bis 1700 . Heidelberg: Winter.

Borgwaldt, Susanne R. 2013. Fugenelemente und Bindestriche in neugebildeten NN-Komposita. In Die Schnittstelle von Morphologie und geschriebener Sprache [Linguistische Arbeiten 551], Martin Neef \& Carmen Scherer (eds), 103-134. Berlin \& New York: de Gruyter.

Bödiker, Johannes. 1701. Neu vermehrte Grundsätze der deutschen Sprachen im Reden und Schreiben. Berlin: Meyer/Zimmermann.

Carr, Charles T. 1933. The position of the genitive in German. The Modern Language Review 28: 465-479.

DTA $=$ Berlin-Brandenburgische Akademie der Wissenschaften. 20072015. Deutsches Textarchiv, <www.deutschestextarchiv.de> (11 February 2017).

Demske, Ulrike. 1999. Case compounds in the history of German. In $\mathrm{Va}$ riation und Stabilität in der Wortstruktur. Untersuchungen zu Entwicklung, Erwerb und Varietäten des Deutschen und anderer Sprachen, Matthias Butt \& Nanna Fuhrhop (eds), 150-176. Hildesheim: Olms. 
Demske, U1rike. 2001. Merkmale und Relationen. Diachrone Studien zur Nominalphrase des Deutschen. Berlin \& New York: de Gruyter.

$\mathrm{DR}=$ 2011. Deutsche Rechtschreibung. Regeln und Wörterverzeichnis. Entsprechend den Empfehlungen des Rats für deutsche Rechtschreibung. Überarbeitete Fassung des amtlichen Regelwerks 2004 mit den Nachträgen aus dem Bericht 2010. München, Mannheim. $<$ http://rechtschreibrat.ids-mannheim.de/download/regeln2006.pdf> (18 January 2017).

Durrell, Martin, Astrid Ensslin \& Paul Bennett. 2007. The GerManC project. Sprache und Datenverarbeitung 31: 71-80.

Ebert, Robert Peter. 1988. Variation in the position of the attributive genitive in sixteenth century German. Monatshefte für den deutschen Unterricht, deutsche Sprache und Literatur 80: 31-49.

Fuhrhop, Nanna. 1998. Grenzfälle morphologischer Einheiten. Tübingen: Stauffenburg.

Grube, Henner. 1976. Die Fugenelemente in neuhochdeutschen appellativischen Komposita. Sprachwissenschaft 1: 187-222.

Heller, Klaus. 2000. „Binde-Strich“ und „Zergliederungs-Sucht“. Sprachreport 1: 26-27.

Henzen, Walter. 1957. Deutsche Wortbildung, 2nd edn. Tübingen: Niemeyer.

Klein, Andreas. 2015. Instrumentenklänge und Temperamentszustände Fälle zwischen -en und -s. Zur unparadigmischen en-Fuge in Lehnwortkomposita: Genese und Distribution. Unpublished term paper, University of Mainz.

Kopf, Kristin. 2016. Von der Syntax in die Wortbildung. Zur Diachronie der verfugenden $N+N$-Komposition. Dissertation: University of Mainz. 
Kopf, Kristin. 2017. Die Compositions-Fuge. Zur Herausbildung phonologischer und graphematischer Grenzmarkierungen in (früh)neuhochdeutschen N+N-Komposita. In Sichtbare und hörbare Morphologie [Linguistische Arbeiten 565], Nanna Fuhrhop, Renata Szczepaniak \& Karsten Schmidt (eds), 177-204. Berlin \& Boston: de Gruyter.

Kürschner, Sebastian. 2003. Von Volk-s-musik und Sport- Ø-geist im Lemming- $\varnothing$-land - af folk-e-musik og sport-s-ånd i lemming-elandet: Fugenelemente im Deutschen und Dänischen - eine kontrastive Studie zu einem Grenzfall der Morphologie. MA thesis, University of Freiburg.

<http://www.freidok.uni-freiburg.de/volltexte/1256/> (04 June 2017)

Nitta, Haruo. 1987. Zur Erforschung der , uneigentlichen`Zusammensetzungen im Frühneuhochdeutschen. Zeitschrift fïr deutsche Philologie 106: 400-416.

Nübling, Damaris, Fabian Fahlbusch \& Rita Heuser. 2012. Namen. Eine Einführung in die Onomastik. Tübingen: Narr.

Nübling, Damaris \& Renata Szczepaniak. 2008. On the way from morphology to phonology: German linking elements and the role of the phonological word. Morphology 18: 1-25.

Nübling, Damaris \& Renata Szczepaniak. 2011. Merkmal(s?)analyse, Seminar(s?)arbeit und Essen(s?)ausgabe: Zweifelsfälle der Verfugung als Indikatoren für Sprachwandel. Zeitschrift für Sprachwissenschaft 30: 45-73.

Nübling, Damaris \& Renata Szczepaniak. 2013. Linking elements in German. Origin, change, functionalization. Morphology 23: 67-89. 
Pavlov, Vladimir M. 1983. Von der Wortgruppe zur substantivischen Zusammensetzung. Zur Ausbildung der Norm der deutschen Literatursprache (1470-1730), vol. 4. Berlin: Akademie-Verlag.

Scherer, Carmen. 2012. Vom Reisezentrum zum Reise Zentrum. Variation in der Schreibung von N+N-Komposita. In Das Deutsche als kompositionsfreudige Sprache. Strukturelle Eigenschaften und systembezogene Aspekte [Linguistik - Impulse \& Tendenzen 46], Livio Gaeta \& Barbara Schlücker (eds), 57-81. Berlin \& New York: de Gruyter.

Schlücker, Barbara. 2012. Die deutsche Kompositionsfreudigkeit. Übersicht und Einführung. In Das Deutsche als kompositionsfreudige Sprache. Strukturelle Eigenschaften und systembezogene Aspekte [Linguistik - Impulse \& Tendenzen 46], Livio Gaeta \& Barbara Schlücker (eds), 1-25. Berlin \& New York: de Gruyter.

Schlücker, Barbara. Genitives and proper name compounds in German. In this volume.

Schottel, Justus Georg. 1663. Ausführliche Arbeit Von der Teutschen HaubtSprache. Braunschweig: Zilliger.

Solling, Daniel. 2012. Zur Getrennt-, Zusammen- und Bindestrichschreibung von Substantivkomposita im Deutschen (1550-1710). Dissertation, University of Uppsala.

Wegener, Heide. 2003. Entstehung und Funktion der Fugenelemente im Deutschen, oder: warum wir keine *Autosbahn haben. Linguistische Berichte 196: 425-457.

Wegener, Heide. 2008. The regrammaticalization of linking elements in German. In Theoretical and Empirical Issues in Grammaticalization [Typological Studies in Language 77], Elena Seoane \& Mariá José 
López-Couso (eds), 333-354. Amsterdam \& Philadelphia: Benjamins.

Wurzel, Wolfgang Ulrich. 1996. Morphologischer Strukturwandel: Typologische Entwicklungen im Deutschen. In Deutsch - typologisch, Ewald Lang \& Gisela Zifonun (eds), 492-524. Berlin \& New York: de Gruyter. 